Lingua Rima: Jurnal Pendidikan Bahasa dan Sastra Indonesia

Vol. 10 No. 1 Januari 2021

http://jurnal.umt.ac.id/index.php/lgrm

\title{
ANALISIS KESALAHAN BERBAHASA PADA BALIHO MAKANAN (KAJIAN MORFOLOGI)
}

\author{
Hamdani Fajar Apriwulan ${ }^{1}$ \\ Universitas Ahmad Dahlan \\ hamdanifajar29@gmail.com ${ }^{1}$ \\ Tutut Romania ${ }^{2}$ \\ Universitas Ahmad Dahlan \\ tututarmaniya@gmail.com \\ Mita Restiana ${ }^{3}$ \\ Universitas Ahmad Dahlan \\ mitarestiana10@gmail.com
}

\begin{abstract}
ABSTRAK
Penelitian ini bertujuan untuk mengetahui kesalahan berbahasa bidang morfologi pada media spanduk atau baliho makanan. Penelitian ini merupakan penelitian kualitatif dengan metode analisis isi. Data yang digunakan dalam penelitian ini yaitu kalimat yang mengandung kesalahan berbahasa dalam tataran morfologi pada baliho makanan di foto artikel internet. Sumber data yang digunakan yaitu baliho yang terdapat dalam foto artikel di internet. Teknik pengumpulan data menggunakan teknik baca dan catat. Teknik analisis data yaitu menggunakan teknik reduksi data, penyajian data dan penarikan simpulan. Berdasarkan data yang ditemukan dan dianalisis dapat disimpulkan bahwa tulisan pada baliho makanan masih sering dijumpai kesalahan berbahasa dalam tataran morfologi berkaitan dengan penulisan kata. Penelitian ini meneliti lima data yang berkaitan dengan kesalahan kata baku dan tidak baku, singkatan kata, penulisan huruf.
\end{abstract}

Kata Kunci: kesalahan berbahasa, morfologi, baliho makanan

\section{A. PENDAHULUAN}

Bahasa juga merupakan media bagi setiap manusia untuk menyampaikan ide, pikiran, gagasan, konsep, dan perasaan. Susunan huruf, kata dan kalimat sangat mempengaruhi makna dalam berbahasa. Penempatan susunan huruf, kata dan kalimat juga harus tepat sehingga tidak memberikan makna yang menyimpang dari tuturan yang dimaksud. Maka, lawan bicara dapat memahami makna yang diujarkan oleh penutur. Akan tetapi, mayoritas masyarakat masih rancu dalam menempatkan kata dalam kalimat. Disadari atau tidak, penggunaan kata sering sekali tidak tepat dalam pemakaiannya.

Disamping itu, kerancuan dalam susunan kalimat memberikan penafsiran ganda (ambigu) atau bahkan memberikan makna berbeda dengan makna yang dimaksudkan oleh penutur. Mayoritas masyarakat tidak memperhatikan atau tidak peduli dengan kesalahan berbahasa tersebut, yang terpenting tujuan dan maksud mereka tersampaikan. Masyarakat hanya mementingkan informasi dapat tersampaikan. Kesalahan-kesalahan tersebut banyak 


\section{Lingua Rima: Jurnal Pendidikan Bahasa dan Sastra Indonesia \\ Vol. 10 No. 1 Januari 2021 \\ http://jurnal.umt.ac.id/index.php/lgrm}

dijumpai dalam berbagai bentuk misalnya surat, pengumuman, memo, bahkan spanduk atau baliho.

Kesalahan penggunaan kalimat pada baliho makanan banyak terjadi. Banyak penjual tidak memperhatikan penggunaan bahasa baku atau EYD dalam menuliskan baliho. Penjual hanya memikirkan kata-kata yang dapat dibaca dan terdengar akrab bagi pelanggan tanpa memperhatikan EYD. Hal tersebut akan berdampak makin maraknya penggunaan bahasa tidak baku. Apabila penjual memperhatikan penggunaan EYD, maka penggunaan EYD akan lebih diperhatikan. Padahal masyarakat juga memiliki peranan penting dalam melestarikan kaidah kebahasaan.

Kesalahan berbahasa biasanya ditentukan berdasarkan ukuran keberterimaan. Jika pembelajar bahasa Indonesia membuat kesalahan, maka ukuran yang digunakan adalah apakah kata atau kalimat yang digunakan pembelajar benar atau salah menurut penutur asli bahasa Indonesia. Jika kata atau kalimat yang digunakan pembelajar bahasa tadi salah, dikatakan pembelajar bahasa membuat kesalahan. Ukuran kesalahan dan ketidaksalahan intrabahasa adalah ukuran kebahasaan. Ukuran kebahasaan meliputi fonologi (tata bunyi), morfologi (tata kata), sintaksis (tata kalimat) dan semantik (tata makna) (Mutiadi \& Patimah, 2016).

Kesalahan berbahasa dapat terjadi dalam situasi bahasa apapun, kesalahan bisa terjadi ketika seseorang sedang mempelajari bahasa tertentu ataupun kesalahan bisa terjadi pula terhadap seseorang yang sudah fasih dalam hal berbahasa. Terdapat lima jenis daerah kesalahan berbahasa dengan satu sifat kesalahan di dalamnya, yaitu daerah kesalahan fonologi, morfologi, sintaksis, semantik, dan kesalahan memfosil sebagai sifat kesalahan dalam berbahasa (Astuti, Sobari, \&Aeni, 2020:23).

Jika morfologi mengarah pada pembentukan katanya. Fonologi kesalahan dalam pelafalan bunyinya sedangkan bahasa baku lebih kepada penggunaan bahasa yang tidak sesuai kaidah kebahasaan. Selain itu ketidak pahaman penggunaan tanda baca, menyebabkan banyak tulisan-tulisan di spanduk, papan nama, selembaran, dan mading. Banyak ditemui kata yang tidak baku dan juga ditemukan kesalahan dalam penulisan tanda baca yang tidak sesuai dengan ejaan yang disempurnakan. Hal itulah yang menyebabkan dalam sebuah tulisan kerap tidak sesuai dengan EYD ataupun bahasa baku.

Sebagai bahasa baku, terdapat standar tertentu yang harus dipenuhi dalam penggunaan ragam bahasa. Standar tersebut meliputi penggunaan tata bahasa dan ejaan bahasa Indonesia yang disempurnakan. Tata bahasa Indonesia yang baku salah satunya meliputi penggunaan 


\section{Lingua Rima: Jurnal Pendidikan Bahasa dan Sastra Indonesia \\ Vol. 10 No. 1 Januari 2021 \\ http://jurnal.umt.ac.id/index.php//grm}

kata, dan EYD yang sesuai dengan kaidah baku. Kaidah tata bahasa Indonesia yang baku adalah kaidah tata bahasa Indonesia sesuai dengan aturan berbahasa yang ditetapkan oleh Pusat Bahasa Indonesia. Sementara itu, kaidah ejaan bahasa Indonesia yang baku adalah kaidah ejaan bahasa Indonesia yang disempurnakan.

Kesalahan yang sering terjadi pada tataran morfologi dapat dilihat dari proses pembubuhan afiks, pemajemukan kata dasar sehingga menjadi arti baru serta pengulanganpengulangan kata yang tidak perlu. Sedangkan, kesalahan pada tataran sintaksis berhubungan dengan makna yang juga harus disesuaikan serta semantik mengkaji kesalahan dalam kalimat (Nisa, 2018:219). Objek morfologi saling berhubungan dengan bentuk atau struktur kata dalam suatu bahasa. Dalam proses pembentukan kata dan alomorf terkait dengan bidang linguistik struktural, morfologi menjadi hal yang penting. Proses morfologis membentu katakata dengan menghubungkan morfem yang satu dengan morfem yang lainnya sehingga membentuk berupa kata, kata dasar, bentuk kompleks, frase, kata dan pokok kata, atau berupa pokok kata dengan pokok kata (Irmawati, Sari, dan Kusumahastuti, 2020:280)

\section{B. METODE PENELITIAN}

Penelitian ini merupakan penelitian kualitatif dengan metode analisis isi. Data yang digunakan dalam penelitian ini yaitu kalimat yang mengandung kesalahan berbahasa dalam tataran morfologi pada baliho makanan di foto artikel internet. Sumber data yang digunakan yaitu baliho yang terdapat dalam foto artikel di internet. Teknik pengumpulan data menggunakan teknik baca dan catat. Peneliti membaca baliho yang terdapat di iklan foto artikel internet kemudian mencatat bagian-bagian yang terdapat kesalahan berbahasa dalam tataran morfologi. Teknik analisis data yaitu menggunakan teknik reduksi data, penyajian data dan penarikan simpulan. Peneliti mereduksi data yang telah dikumpulkan dan disesuaikan dengan data kesalahan berbahasa dalam tataran morfologi. Peneliti menyajikan data menggunakan deskripsi data. Peneliti melakukan penarikan simpulan dari data yang telah dianalisis.

\section{HASIL PENELITIAN DAN PEMBAHASAN}

Penelitian tentang media luar ruang pada hakikatnya memiliki banyak aspek yang bisa diteliti, seperti kesalahan berbahasa, analisis wacana, dan sebagainya. Akan tetapi, penelitian ini hanya menganalisis tentang kesalahan pemakaian bahasa Indonesia. Aspek kesalahan berbahasa yang dianalisis meliputi kesalahan dalam bidang huruf, tanda baca, singkatan, akronim, dan unsur asing. Ada lima contoh kesalahan berbahasa pada media luar ruang yang kami analisis. Contoh diambil berdasarkan pada kesalahan dalam penulisan tempat, penulisan 
Lingua Rima: Jurnal Pendidikan Bahasa dan Sastra Indonesia

Vol. 10 No. 1 Januari 2021

http://jurnal.umt.ac.id/index.php//grm

kata baku dan tidak baku, penulisan pada kata ganti, penulisan pada kata depan, dan penulisan pada kata tempat.

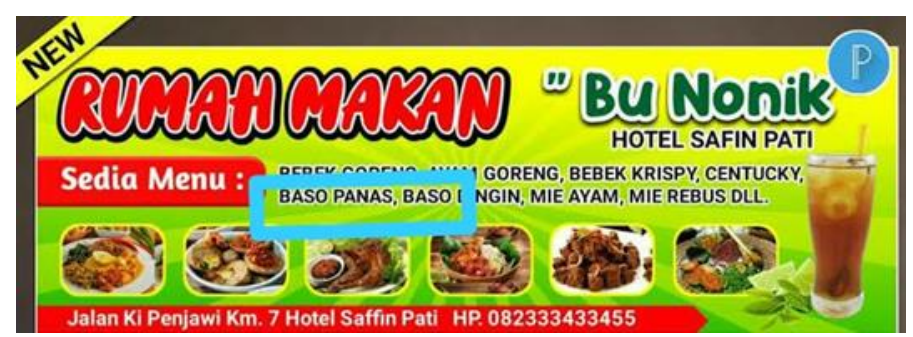

Data 1

Pada penulisan baliho makanan ini terdapat kesalahan dalam penulisan kata baku menjadi tidak baku yaitu pada penulisan kata baso. Alternatif pembenaran pada penulisan tersebut adalah bakso, dengan keterangan bahwa kata baso adalah bentuk kata tidak baku dari bakso sehingga penulisan yang benar adalah bakso. Kata baku merupakan sebuah kata yang digunakan sudah sesuai dengan pedoman atau kaidah bahasa yang sudah di tentukan, atau kata baku merupakan kata yang sudah benar dengan aturan maupun ejaan kaidah bahasa Indonesia dan sumber utama dari bahasa baku yakni Kamus Besar Bahasa Indonesia.

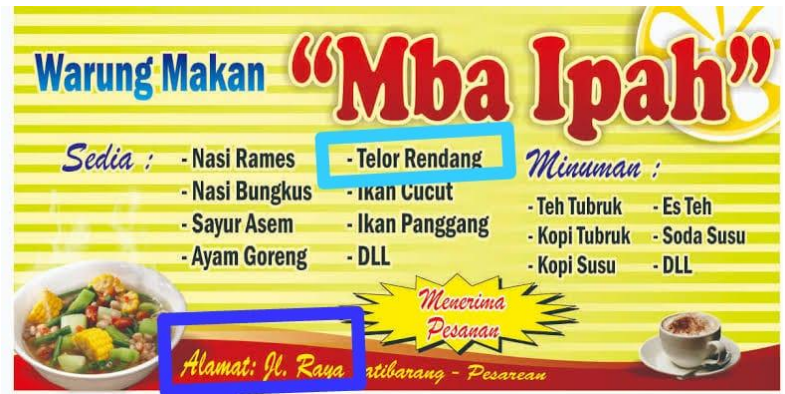

Data 2

Baliho di atas terdapat dua kesalahan berbahasa. Kesalahan yang pertama ditandai dengan kotak berwarna biru muda, sedangkan kesalahan yang kedua kotak berwarna biru tua. Kesalahan yang pertama ini merupakan kesalahan berbahasa Indonesia baku dan tidak baku. Kata telor yang dimaksud dalam kotak biru muda ini merupakan telur yaitu benda bercangkang yang mengandung zat hidup bakal anak yang dihasilkan oleh unggas (ayam, itik, burung, dan sebagainya) biasanya dimakan (direbus, di ceplok, didadar dan sebagainya). Namun penulisannya memiliki kesalahan, karena yang tertulis pada baliho tersebut adalah Telor. Kata Telor sendiri menurut Kamus Besar Bahasa Indonesia (KBBI) memiliki arti tidak dapat mengucapkan kata-kata dengan lafal yang betul (seperti kurang diucapkan kulang). Kesalahan yang kedua atau yang terdapat pada kotak berwarna biru tua. Kesalahan 
Lingua Rima: Jurnal Pendidikan Bahasa dan Sastra Indonesia

Vol. 10 No. 1 Januari 2021

http://jurnal.umt.ac.id/index.php//grm

ini merupakan kesalahan pada penulisan singkatan. Singkatan kata jl merupakan kesalahan berbahasa pada penulisan. Karena penulisan yang benar yaitu jalan atau jika ingin disingkat bisa dengan penulisan jln.

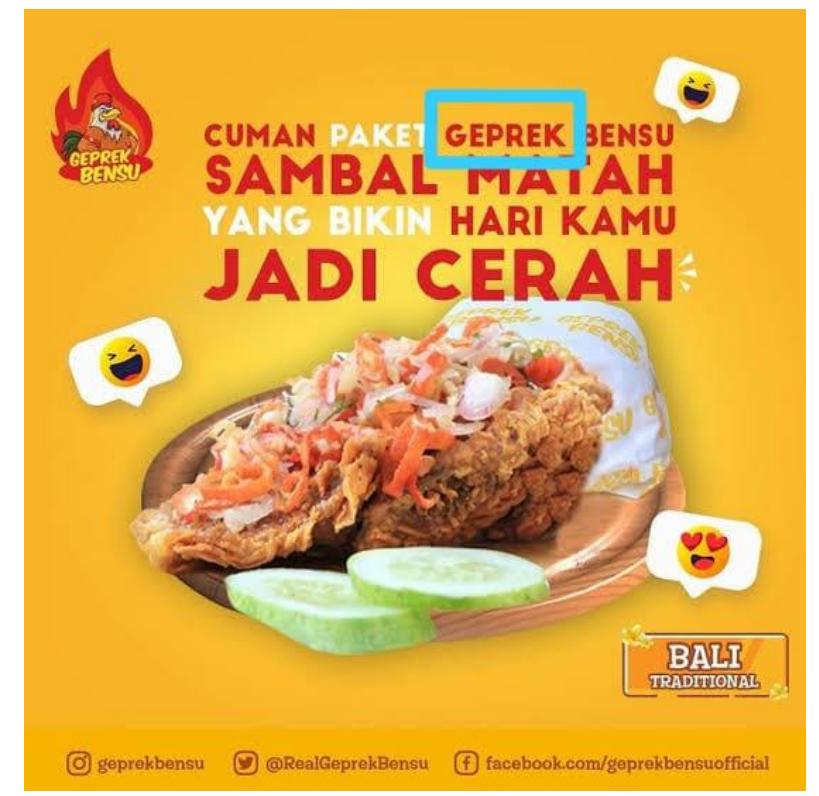

\section{Data 3}

Pada baliho makanan ini terdapat kesalahan berbahasa Indonesia berupa kata baku dan tidak baku. Kata baku yang berada dalam kotak berwarna biru muda ini merupakan kata tidak baku dari geprak. Menurut Kamus Besar Bahasa Indonesia (KBBI) kata geprak berarti tiruan bunyi galah dipukulkan ke kelompok dahan dan daun dengan keras. Menurut saya kata yang tepat untuk mewakili ayam yang berbentuk pipih ini lebih mengarah ke penyek. Karena kata penyek dalam KBBI merupakan sesuatu yang berbentuk pipih karena terimpit atau sebagainya.

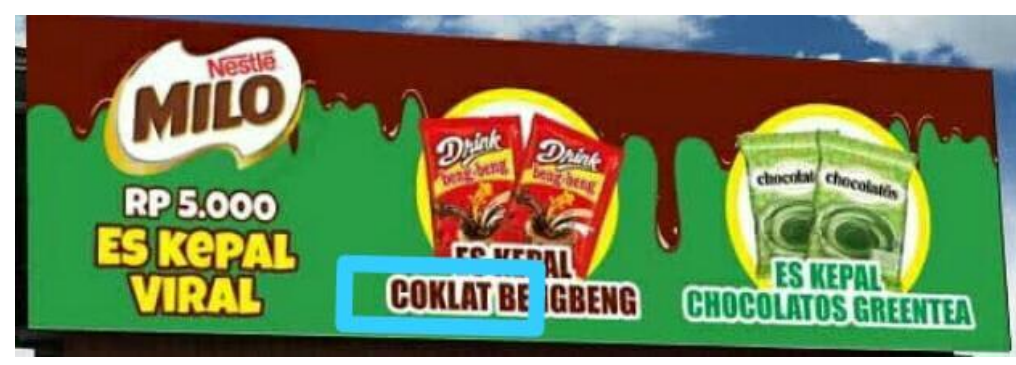

Data 4

Kesalahan ini merupakan kesalahan berbahasa Indonesia baku dan tidak baku. Pada penulisan baliho makanan ini terdapat kesalahan dalam penulisan kata baku menjadi tidak baku yaitu pada penulisan kata coklat. Kata coklat pada baliho tersebut yang dimaksud 


\section{Lingua Rima: Jurnal Pendidikan Bahasa dan Sastra Indonesia \\ Vol. 10 No. 1 Januari 2021 \\ http://jurnal.umt.ac.id/index.php//grm}

adalah cokelat dalam KBBI (gula-gula yang dibuat dari bubuk cokelat). Kata coklat adalah bentuk kata tidak baku dari cokelat, sehingga penulisan yang benar adalah cokelat.

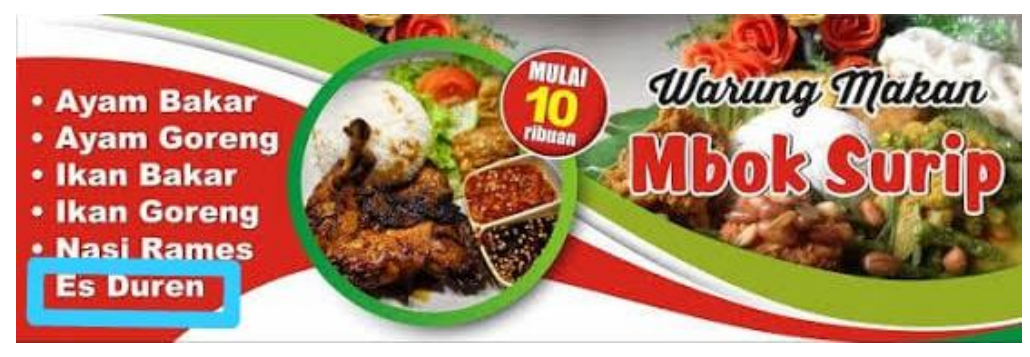

Data 5

Kesalahan ini merupakan masih kesalahan berbahasa Indonesia baku dan tidak baku. Pada penulisan baliho makanan ini terdapat kesalahan dalam penulisan kata baku menjadi tidak baku yaitu pada penulisan kata duren. Kata duren pada baliho tersebut yang dimaksud adalah durian dalam KBBI (buah durian, berkulit tebal dan berduri, berbentuk bundar lonjong atau bundar telur, dagingnya berwarna putih, kuning tua atau putih kekuningkuningan, berbau tajam dan dapat memabukkan). Kata duren adalah bentuk kata tidak baku dari durian, sehingga penulisan yang benar adalah durian.

\section{SIMPULAN DAN SARAN}

Berdasarkan data yang ditemukan dan dianalisis dapat disimpulkan bahwa tulisan pada baliho makanan masih sering dijumpai kesalahan berbahasa dalam tataran morfologi berkaitan dengan penulisan kata. Penelitian ini meneliti lima data yang berkaitan dengan kesalahan kata baku dan tidak baku, singkatan kata, penulisan huruf. Penelitian ini juga banyak dijumpai pemilihan kata yang tidak tepat sehingga menimbulkan makna yang berbeda. Kesalahan berbahasa yang sering terjadi karena kurangnya pemahaman dalam menulis tanpa memperhatikan pemilihan makna dan kaidah bahasa yang benar.

\section{E. DAFTAR PUSTAKA}

Astuti, S.P., Sobari, T., \& Aeni, E.S. 2020. Analisis Kesalahan Berbahasa Tataran Fonologi dan Morfologi pada Penulisan Teks Eksplanasi Siswa Kelas VIII SMP PGRI 4 Cimahi. Jurnal Parole. Vol 3 No 1 PP 21-30

Irmawati, E., Sari, N. P. I., \& Kusumahastuti, P. A. 2020. Analisis Kesalahan Berbahasa Bidang Morfologi dan Ejaan apada Judul Youtube di Chanel Baim Paula. Jurnal Diglosia. Vol 4 No 2 PP 277-289

Mutiadi, A. D., \& Patimah, I. 2016. Analisis Kesalahan Morfologis dan Sintaksis pada Pidato Presiden Joko Widodo Periode Januari 2015. Jurnal Fon. Vol 8 No 1

Nisa, K. 2018. Analisis Kesalahan Berbahasa pada Berita dalam Media Surat Kabar Sinar Indonesia Baru. Jurnal Bindo Sastra. Vol 2 No 2 PP 218-224 